\title{
A mortality study of workers manufacturing friction materials: $1941-86$
}

\author{
M L NEWHOUSE, K R SULLIVAN
}

From the TUC Centenary Institute of Occupational Health, London School of Hygiene \& Tropical Medicine, London WC1E 7HT, UK

ABSTRACT The mortality of workers employed at a factory producing friction materials has been studied from 1941 to 1986 , extending a previous study by seven years. Apart from two periods before 1944, when crocidolite asbestos was used on one particular contract, only chrysotile asbestos has been $\vec{\sigma}$ used. Thirteen deaths were attributed to mesothelioma and of these, 11 were of subjects who had $\omega$ known contact with crocidolite asbestos. Of the remaining two, in one instance the diagnosis is $\vec{\nabla}$ uncertain and in the other the occupational history of the subject is not well established. There was no excess of deaths from lung cancer or other asbestos related tumours, or from chronic respiratory disease. After 1950 hygienic control was progressively improved and from 1970 levels of asbestos in air have not exceeded $0.5-1.0 \mathrm{f} / \mathrm{ml}$. It is concluded that with good environmental control chrysotile asbestos may be used in manufacture without causing excess mortality.

A mortality study of workers employed between 1941 and 1979 at a factory producing friction materialsthat is, chiefly brake blocks and brake and clutch linings - was reported in $1982 .^{12}$

The factory concerned has employed both men and women since its foundation in 1898: the main processes carried out being the coating of fibre in resin, followed by the forming, shaping, and machining of the friction material. Only chrysotile asbestos was used in the factory apart from two well defined short periods before 1944 when crocidolite asbestos was used for a particular contract. The previous study reported 10 deaths from pleural mesothelioma, nine relating to subjects who had contact with crocidolite asbestos. There was no detectable excess mortality among those exposed only to chrysotile asbestos.

The environmental history of the factory has been well documented. ${ }^{3}$ Briefly, before 1931 dust concentrations were high, reaching over $20 \mathrm{fibres} / \mathrm{ml}(\mathrm{f} / \mathrm{ml})$, but they improved after the introduction of the Asbestos Regulations of 1931. From 1931 to 1950 high exposure, 5-20 f/ml, occurred only in the grinding and fibre preparation areas in the factory. After 1950 there was progressive control and throughout the factory exposure was reduced to less than $5 \mathrm{f} / \mathrm{ml}$; since 1970 levels above $0.5-1.0 \mathrm{f} / \mathrm{ml}$ have not been recorded. Because of the economic importance of the product, and of interest in the relative carcinogenicity of chrysotile asbestos compared with that of amphibole asbestos, the study has been continued. The present

Accepted 19 September 1988 report extends the period of observation to December 1986 , giving an extra seven years of follow up.

\section{Method}

In 1941 the factory started an alphabetical filing system of its workforce, recording dates of birth and dates of starting work and leaving employment but omitting job titles. The population studied now consists of 13450 subjects first employed between 1941 and 1979. Of these subjects, 9104 were men and 4346 women; nine men and one woman with unknown dates of birth have been excluded from the original cohort. Emigration status was obtained only to the end of 1979 at which point $2.6 \%$ of the total cohort had emigrated. No further details of the service history of the cohort were obtained after 1979. Death cer- 윽 tificates have continued to be forwarded by the $>$ National Health Service Central Registrar, coded to the 8th revision of the International Classification of $\bar{N}$ Disease (ICD). The results are presented in the same of general format as in the previous communication, ${ }^{2}$ but $N$ chronic respiratory diseases (ICD 460-519, 8th re- స్ట vision) have also been separately identified. Observed mortality was compared with that expected on the basis of sex, age, and period specific death rates using $\frac{C}{\Phi}$ the subject year method, ${ }^{4}$ with $90 \%$ confidence inter- $\stackrel{\infty}{+}$ vals $(90 \% \mathrm{CI})$ of the standardised mortality ratios $\square$ (SMRs) used to indicate statistical significance. This level of interval was chosen as an appropriate indi- ̊ cator of excess mortality in a cohort known a priori to 
Table 1 Mortality patterns after 10 years from first employment

\begin{tabular}{|c|c|c|c|c|c|c|}
\hline & \multicolumn{3}{|c|}{$\operatorname{Men}(n=8404)$} & \multicolumn{3}{|c|}{ Women $(n=4167)$} \\
\hline & \multicolumn{2}{|c|}{ Subject years } & \multirow{2}{*}{$\frac{148135}{\operatorname{SMR}(90 \% C I)}$} & \multicolumn{2}{|c|}{ Subject years } & \multirow{2}{*}{$\frac{84249}{\operatorname{SMR}(90 \% C I)}$} \\
\hline & Obs & $\operatorname{Exp}$ & & Obs & $\operatorname{Exp}$ & \\
\hline $\begin{array}{l}\text { All causes } \\
\text { Lung and pleural cancer } \\
\text { Gastrointestinal cancer } \\
\text { Other cancers } \\
\text { Respiratory disease } \\
\text { Other causes }\end{array}$ & $\begin{array}{l}2055 \\
240(11)^{*} \\
156 \\
134 \\
227 \\
1298\end{array}$ & $\begin{array}{r}2067 \cdot 6 \\
221 \cdot 4 \\
167 \cdot 1 \\
146 \cdot 3 \\
261 \cdot 4 \\
1271 \cdot 3\end{array}$ & $\begin{array}{r}99(96-103) \\
108(97-120) \\
93(81-106) \\
92(79-105) \\
87 \dagger(77-96) \\
102(97-107)\end{array}$ & $\begin{array}{l}522 \\
14(2)^{*} \\
46 \\
88 \\
33 \\
341\end{array}$ & $\begin{array}{r}578 \cdot 7 \\
21 \cdot 1 \\
46 \cdot 8 \\
103 \cdot 1 \\
61 \cdot 5 \\
346 \cdot 2\end{array}$ & $\begin{array}{l}90(84-97) \\
66(40-104) \\
98(74-122) \\
85(70-100) \\
54+(38-69) \\
98(90-107)\end{array}$ \\
\hline
\end{tabular}

$*()=$ Number of pleural mesotheliomas.

†Significantly lower than $100, p<0.01$, two sided test.

have little if any overall excess mortality. For SMRs based on $\mathbf{3 0}$ or fewer deaths confidence intervals were computed with the exact method based on the Poisson distribution. The normal approximation was used for others.

\section{Results}

A further 769 deaths have been recorded in the additional seven years, giving a total of 2371 male deaths $(26.0 \%$ of the men) and $571(13.1 \%)$ female deaths. Attention has been restricted to the period following 10 years from first employment; in this period we have a total of 2055 male and 522 female deaths. Three further deaths from pleural mesothelioma have occurred in these seven years, giving a total of 13 over the total study period 1941-86. Apart from these 13 deaths due to mesothelioma there is no evidence of an excess mortality (table 1). There is evidence of a reduced mortality from chronic respiratory diseases (SMR 87 in men and 54 in women, both significantly below 100). In the group "other causes," six deaths in men were from cancer of the larynx (expected 9.4, SMR 64, 90\% CI 28-126), 40 in women from cancer of breast (expected 43.4, SMR 92, $90 \% \mathrm{CI} 70-120$ ), and 11 in women from cancer of the ovary (expected 10.1, SMR 108, 90\% CI 61-179). Comparison of the SMRs at 1979 and 1986 (table 2) show remarkably similar values, with no SMR significantly raised above 100 ; here chronic respiratory diseases are grouped with "other causes" to allow comparison with the 1979 results. The SMR for cancer of the gastrointestinal tract has declined both in men and women, and for lung and pleural cancer the SMR appears to have fallen in women.

Repeating the analysis for the group at highest risk - that is, those with 10 or more years employment in the factory and with a follow up of 20 or more years (table 3)-also shows no statistically significant excess in mortality apart from the 10 deaths due to pleural mesothelioma occurring in this group of subjects. Here the SMR for lung cancer is 118 in men and 110 in women and the SMR for cancer of the gastrointestinal tract is 89 in men and 123 in women. There is again evidence of reduced mortality from chronic respiratory disease.

Considering lung and pleural cancer alone it is clear that if SMRs are related to the start of first employment in the factory (table 4) then those who were at work before 1941 were at the greatest risk, this being well before the progressively improved control of environmental conditions introduced after 1950.

\section{MESOTHELIOMA AND ASBESTOSIS}

The first of the three additional deaths from a pleural mesothelioma occurred in November 1980 and has been reported before ${ }^{2}$ but was not included in the previous analysis. The man concerned had worked for two weeks in the factory as a grinder in 1960 at the age

Table 2 Standardised mortality ratios at 1979 and 1986 after 10 years from first employment

\begin{tabular}{|c|c|c|c|c|}
\hline & \multicolumn{2}{|l|}{ Men } & \multicolumn{2}{|l|}{ Women } \\
\hline & 1979 & 1986 & 1979 & 1986 \\
\hline $\begin{array}{l}\text { All causes } \\
\text { Lung and pleural cancer } \\
\text { Gastrointestinal cancer } \\
\text { Other cancers } \\
\text { Other diseases (including respiratory disease) }\end{array}$ & $\begin{array}{l}98(94-103)^{*} \\
108(94-123) \\
96(81-112) \\
88(71-104) \\
98(93-103)\end{array}$ & $\begin{array}{r}99(96-103) \\
108(97-120) \\
93(81-106) \\
91(79-105) \\
99(95-104)\end{array}$ & $\begin{array}{r}91(82-100) \\
71(35-128) \\
106(76-144) \\
85(65-105) \\
92(82-102)\end{array}$ & $\begin{array}{l}90(84-97) \\
66(40-104) \\
98(74-122) \\
85(70-100) \\
92(84-100)\end{array}$ \\
\hline
\end{tabular}

*90\% Confidence interval. 
Table 3 Mortality after 20 years from first employment for workers with 10 years or more employment

\begin{tabular}{|c|c|c|c|c|c|c|}
\hline & \multicolumn{3}{|c|}{$\operatorname{Men}(n=2222)$} & \multicolumn{3}{|c|}{ Women $(n=608)$} \\
\hline & \multicolumn{2}{|c|}{ Subject years } & \multirow{2}{*}{$\frac{33085}{S M R(90 \% C I)}$} & \multicolumn{2}{|c|}{ Subject years } & \multirow{2}{*}{$\frac{11630}{\operatorname{SMR}(90 \% C I)}$} \\
\hline & $O b s$ & $\operatorname{Exp}$ & & Obs & $\operatorname{Exp}$ & \\
\hline $\begin{array}{l}\text { All causes } \\
\text { Lung and pleural cancer } \\
\text { Gastrointestinal cancer } \\
\text { Other cancers } \\
\text { Respiratory disease } \\
\text { Other causes }\end{array}$ & $\begin{array}{l}743 \\
97(9)^{*} \\
56 \\
47 \\
75 \\
468\end{array}$ & $\begin{array}{r}790 \cdot 6 \\
82 \cdot 3 \\
62 \cdot 8 \\
54 \cdot 1 \\
112 \cdot 6 \\
478 \cdot 8\end{array}$ & $\begin{array}{r}94(88-100) \\
118(98-137) \\
89(70-109) \\
87(66-108) \\
67+(54-79) \\
98(90-105)\end{array}$ & $\begin{array}{l}126 \\
5(1)^{*} \\
13 \\
25 \\
6 \\
77\end{array}$ & $\begin{array}{r}126 \cdot 7 \\
4 \cdot 5 \\
10 \cdot 5 \\
20 \cdot 9 \\
13 \cdot 5 \\
77 \cdot 2\end{array}$ & $\begin{array}{l}99(85-114) \\
110(43-232) \\
123(73-196) \\
119(83-167) \\
44 \ddagger(19-88) \\
100(81-118)\end{array}$ \\
\hline
\end{tabular}

*( ) = Number cf pleural mesotheliomas.

+Significantly lower than $100, p<0.01$, two sided test.

$\ddagger$ Significantly lower than $100, \mathrm{p}<0.05$, two sided test.

of 29. He was exposed to chrysotile asbestos. No other occupational contact with asbestos has been established.

The second case was of a man who died aged 77 in 1981. He worked at the factory from 1929 to 1975 and was the brother of a woman whose certified cause of death was ruptured myocardium but who was found at necropsy in April 1980 to have pleural mesothelioma. As she had worked only between 1929 and 1934 she is not included in the cohort. Both brother and sister worked in the area where railway brake blocks were made using crocidolite asbestos.

The third death was that of a man who worked in the factory from 1956 to 1975 and died aged 77 in a geriatric ward in 1985. The certified cause of death was "malignant right pleural effusion." The diagnosis of pleural mesothelioma was considered by the physicians but not confirmed by histopathology. No necropsy was performed. He worked at the factory when only chyrosotile asbestos was in use and his past occupation is given as an engine driver. Although this death is correctly coded to 163 in the ICD, the diagnosis of pleural mesothelioma has not been substantiated.

Three deaths were recorded from asbestosis, one woman and two men. The women started work in 1915 and the men in 1936 and 1946. All three had long periods of employment in the factory.

\section{Discussion}

In this 46 year follow up of workers employed at a factory producing friction materials and pre- $\supset$ dominantly using chyrsotile asbestos there is no excess $\overrightarrow{-}$ mortality from cancer of the lung, gastrointestinal tumours, or cancer of the larynx, ovary, or breast. $\frac{\bar{\alpha}}{\mathcal{C}}$ Thirteen deaths were attributed to pleural mesothelioma, 11 of which were of workers who had $\mathscr{\odot}$ contact with crocidolite asbestos during the period it ${ }^{\bullet}$ was in use at the factory. Two deaths occurred in men employed only after 1950 and while working in the factory exposed only to chrysotile asbestos. In one the diagnosis appears to be uncertain and was not sup- $ڤ$ ported by necropsy. The other subject worked at the $\stackrel{\AA}{\perp}$ factory for only two weeks, his main occupation $\overrightarrow{\overrightarrow{\vec{O}}}$ having been fitter mechanic.

After 1951 environmental conditions rapidly improved, although up to 1969 concentrations in certain production areas were sometimes as high as $2-5 \mathrm{f} / \mathrm{ml}$. As about a third of the population worked $\stackrel{\Phi}{=}$ for less than a year the workforce experienced a low? cumulative exposure. The study of an asbestos textile 3 . factory using chrysotile asbestos by Dement et al showed a pronounced increased mortality from lung cancer, ${ }^{5}$ but Thomas et al in their study of an asbestos 0 cement factory found no excess deaths due to lung cancer. ${ }^{6}$ Further confirmation of the lower patho--

Table 4 Lung and pleural cancer by year of start of employment after 10 years from first employment. (Number of mesotheliomas in parentheses)

\begin{tabular}{|c|c|c|c|c|c|c|}
\hline & \multicolumn{3}{|l|}{ Men } & \multicolumn{3}{|c|}{ Women } \\
\hline & Obs & $\operatorname{Exp}$ & $S M R(90 \% C I)$ & $O b s$ & $\operatorname{Exp}$ & $S M R(90 \% C I)$ \\
\hline $\begin{array}{l}\text { Pre-1940 } \\
1941-50 \\
1951-60 \\
1961-70 \\
1971-\end{array}$ & $\begin{array}{c}47(8) \\
114 \\
64(3) \\
14 \\
1\end{array}$ & $\begin{array}{r}30 \cdot 7 \\
107 \cdot 2 \\
66 \cdot 8 \\
15 \cdot 6 \\
1 \cdot 1\end{array}$ & $\begin{array}{l}153 *(116-190) \\
106(90-123) \\
96(76-115) \\
90(54-141) \\
88(4-418)\end{array}$ & $\begin{array}{l}3(1) \\
6(1) \\
4 \\
1 \\
0\end{array}$ & $\begin{array}{r}3 \cdot 0 \\
11 \cdot 6 \\
4 \cdot 8 \\
1 \cdot 5 \\
0.2\end{array}$ & $\begin{array}{c}100(27-258) \\
52(22-102) \\
84(29-192) \\
67(3-317) \\
-\quad(0-15)\end{array}$ \\
\hline
\end{tabular}


genicity of the chrysotile asbestos fibre comes from the study of the mineral fibre contents of lungs of asbestos textile factory workers. ${ }^{7}$ Here the crocidolite and amosite fibre content of the lungs in those dying of carcinoma of the lung, mesothelial tumours, and asbestosis was appreciably above the level of that in the lungs of the control groups, patients unexposed to asbestos and operated on for carcinoma of lung. The chrysotile fibre content was proportionately lower than in the controls in all three categories of disease.

This extended follow up of a cohort of over 13000 workers confirms our previous conclusions that under good environmental conditions chrysotile asbestos products can be manufactured with no detectable excess mortality.

\section{References}

1 Newhouse ML, Berry G, Skidmore JW. A mortality study of workers manufacturing friction materials with chrysotile asbestos. Ann Occup Hyg 1982;26:899-909.

2 Berry G, Newhouse ML. Mortality of workers manufacturing friction materials using asbestos. Br J Ind Med 1983;40:1-7.

3 Skidmore JW, Dufficy B. Environmental history of a factory producing friction materials. $\mathrm{Br}$ J Ind Med 1983;40:8-12.

4 Case RAM, Lea AJ. Mustard gas poisoning, chronic bronchitis and lung cancer. Br J Prev Soc Med 1955;9:62-72.

5 Dement JM, Harris RL, Symons MJ, Shy C. Estimates of dose response for respiratory cancer among chrysotile asbestos textile workers. In: Walton WH, ed. Inhaled particles V. Oxford: Pergamon Press, 1982.

6 Thomas HF, Benjamin IT, Elwood PC, Sweetnam PM. A further follow-up study of workers from an asbestos cement factory. $\mathrm{Br}$ J Ind Med 1982;39:273-6.

7 Wagner JC, Newhouse ML, Corrin B, Rossiter CE, Griffiths DM. Correlation between fibre content of the lung and disease in east London asbestos factory workers. Br J Ind Med 1988;45:305-8.

\section{Destruction of manuscripts}

From 1 July 1985 articles submitted for publication will not be returned. Authors whose papers are rejected will be advised of the decision and the manuscripts will be kept under security for three months to deal with any inquiries and then destroyed. 